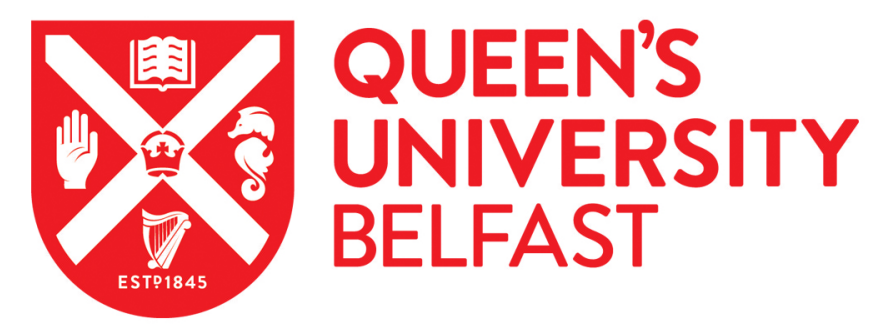

\title{
Smac-derived Aza-peptide As an Aminopeptidase-resistant XIAP BIR3 Antagonist
}

\author{
Elsawy, M. A., Tikhonova, I. G., Martin, L., \& Walker, B. (2015). Smac-derived Aza-peptide As an \\ Aminopeptidase-resistant XIAP BIR3 Antagonist. Protein and Peptide Letters, 22(9), 836-843. \\ https://doi.org/10.2174/0929866522666150622101626
}

\section{Published in:}

Protein and Peptide Letters

\section{Document Version:}

Early version, also known as pre-print

Queen's University Belfast - Research Portal:

Link to publication record in Queen's University Belfast Research Portal

\section{Publisher rights}

(C) 2015 The Authors

\section{General rights}

Copyright for the publications made accessible via the Queen's University Belfast Research Portal is retained by the author(s) and / or other copyright owners and it is a condition of accessing these publications that users recognise and abide by the legal requirements associated with these rights.

Take down policy

The Research Portal is Queen's institutional repository that provides access to Queen's research output. Every effort has been made to ensure that content in the Research Portal does not infringe any person's rights, or applicable UK laws. If you discover content in the Research Portal that you believe breaches copyright or violates any law, please contact openaccess@qub.ac.uk. 


\title{
Smac-Derived Aza-Peptide As an Aminopeptidase-Resistant XIAP BIR3 Antagonist
}

\author{
Mohamed A. Elsawy ${ }^{1,2^{*}}$, Irina G. Tikhonova ${ }^{1}$, S. Lorraine Martin $^{1}$ and Brian Walker ${ }^{1}$
}

${ }^{1}$ School of Pharmacy, Queen's University of Belfast, 97 Lisburn Road, Belfast BT9 7BL, UK; ${ }^{2}$ Manchester Institute of Biotechnology, University of Manchester, 131 Princess Street, Manchester M1 $7 D N, U K$

Abstract: The peptidic nature of anti-IAPs $N$-terminus Smac-derived peptides precludes their utilization as potential therapeutic anticancer agents. Recent advances in the development of novel Smacderived peptidomimetics and non-peptidic molecules with improved anti-IAPs activity and resistance to proteolytic cleavage have been reported and led to a number of candidates that are currently in clinical trials including LCL-161, SM-406/AT-406, GDC-0512/GDC-0917, and birinapant. As an attempt to improve the proteolytic stability of Smac peptides, we developed the Aza-peptide AzaAla-Val-Pro-

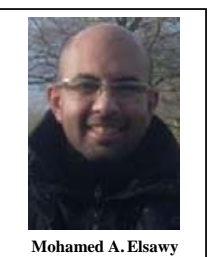
Phe-Tyr- $\mathrm{NH}_{2}$ (2). Unlike unmodified peptide Ala-Val-Pro-Phe- $\mathrm{Tyr}^{-} \mathrm{NH}_{2}$ (1), analogue (2) exhibited resistance towards proteolytic cleavage by two aminopeptidases; LAP and DPP-IV, while retaining its IAP inhibitory activity. This was due to the altered planar geometry of the P1 residue side chain. Our findings showed that using aza-isosteres of bioactive peptide sequences imbue the residue with imperviousness to proteolysis; underscoring a potential approach for developing a new generation of Smac-derived Aza-peptidomimetics.

Keywords: Aminopeptidases, Apoptosis, Aza-peptides, Caspase 9, IAPs, Smac.

\section{INTRODUCTION}

Inhibition of the anti-apoptotic IAPs proteins by short peptides derived from the N-terminal sequence of the proapoptotic mitochondrial protein $\mathrm{Smac}$ is an emerging strategy for re-engaging apop exp for. Although Smac-derived peptides hay demonstrated to augment the activity of anticancer drugs both in-vitro and in-vivo [1,2], their entirely peptidic nature almost certainly precludes their utilization as anticancer therapeutic agents. This is because of the innate and generally impaired bioavailability of peptide ligands mainly due to their instability towards proteolytic cleavage. There have been long standing efforts in developing protease-resistant Smac-derived peptidomimetics (monovalent and bivalent) and non-peptidic analogues by ourselves [3] and many other groups [4-9] that led in some cases to IAP inhibitors that reached clinical trials [10] such as LCL-161 [11,12], SM406/AT-406 [13,14], GDC-0512/GDC-0917 [15,16], and birinapant $[17,18]$, and thus are drug-like compounds with suitable efficacy, bioavailability and tolerability.

Consequently, we have been interested in enhancing the proteolytic resistance of the N-terminal Smac-derived pentapeptide analogue Ala-Val-Pro-Phe-Tyr- $-\mathrm{NH}_{2}(\mathbf{1})$. With regards to the $\mathrm{N}$-terminus Smac sequence, many studies have shown the crucial role of the P1 Ala residue for its IAP inhibitory activity. According to the reported NMR structure

*Address correspondence to this author at the Manchester Institute of Biotechnology, University of Manchester, 131 Princess Street, Manchester M1 7DN, UK; Tel: +44 (0) 7514 896661; E-mail: melsawy01@qub.ac.uk
(PDB: 1G3F) [19], P1 Ala is involved in electrostatic interaction with the proximal Glu314 of XIAP BIR3 through the N-terminal amino group (Fig. 1-3], PDB: 1G3F [19]). Also, the Ala a- methyl group snugly fits into the hydrophobic pocket formed by W310, interacting with the indole ring of the pocket (Fig. 1 [3], PDB: 1G3F [19]). Thus, protecting the crucial P1 Ala residue against hydrolysis by aminopeptidases has to be achieved without interference with these key interactions.

Since the acylation of the amino function of the P1 Ala residue of Smac abolished the binding affinity of the Smac peptide to XIAP BIR3 [19], as did N,N-dimethylation [4], such structural modifications cannot be applied for hindering the possible exposure of the N-terminal segment of the peptide to proteolytic cleavage. It is worth mentioning here that only the N-terminally mono-methylated (N-methyl) Smacderived peptides have preserved IAP inhibitory activity [4] and the-this modification is thus currently widely used as an aminopeptidase resistant residue at $\mathrm{P} 1$ in the Smac-derived peptidomimetic and in non-peptidic clinical candidates [1118].

Based on the above discussed SAR, we have investigated the replacement of the N-terminal alanine of peptide (1) with aza-alanine (AzaAla) residue. Many studies demonstrated that the incorporation of aza-amino acids into susceptible peptidase cleavage sites in peptides renders them less likely to be hydrolysed and thus enhancing the peptide sequence metabolic stability, biological action and elongating the duration of action [21]. We had anticipated that the 




Figure 1. Smac/DIABLO-derived $\mathrm{N}$ terminal sequence $\mathrm{AVPI}$ (orange) in the XIAP BIR3 binding pocket; generated from PDB; 1G3F [19]. Only residues forming the direct contacts with the pep tide are visulized and the shape of the binding cavity is shown with the surfactike of the negative and positive charge residues. Reprinted from Bioorganic and Medicinal Chemistry 2013, 21, Elsawy M. A., Martin L., Tikhenova I. G., Walker B., Solid phase synthesis of Smac DIABLO derived peptides using a'Safety Catch' resin: Identifiea tion of potent XIAP BIR3 antagonists, 5004-5011, Copyright 2013, with permission from Elsevier [3],

modified peptide AzaAla-Val-Pro-Phe-Tyr- $\mathrm{NH}_{2}$ (2) could still make the important electrostatic contacts within the XIAP BIR3 binding pocket, by virtue of the retained and unmodified primary amino function of the AzaAla residue, whilst exhibiting enhanced stability towards aminopeptidases (exemplified mainly by LAP). All this is due to the altered geometry at $\mathrm{P} 1$, where the side chain residue of the $\mathrm{SP}^{2}$ hybridised aza-amino acid is considered to adopt a planar conformation when compared to the tetrahedral conformation of the natural $\mathrm{SP}^{3}$ hybridised L- amino acid (Fig. 2). This letter thus reports on the synthesis of the Smac-derived Azapeptide (2), testing its stability towards LAP compared to peptide (2), testing its stability towards LAP compared to
peptide (1), and an examination of its ability to re-engage caspase-9 activation for apoptosis in cell lysates obtained from MDA-MB-231 breast cancer cells.



Figure 2. Configuration of L-Ala and AzaAla residues.

\section{METHODS}

General Protocol for the Microwave Assisted Solid Phase Peptide Synthesis (MW-SPPS)

Peptides were synthesized using MW-SPPS on Rink Amide MBHA resin (substitution $0.65 \mathrm{mmol} / \mathrm{g}, 100-200 \mathrm{mesh}$ ) and were purified by RP-HPLC as previously described [3].
1-(tert-Butoxycarbonyl)-2-(9H-fluoren-9-methoxycarbonylamino)-1-methylhydrazine (4)

To a stirred solution of 1-(tert-butoxycarbonyl)-1methylhydrazine (12) $(8.1 \mathrm{~g}, 55.4 \mathrm{mmol})$ in $\mathrm{THF} / \mathrm{H}_{2} \mathrm{O}(70 / 70$ $\mathrm{mL}$ ) in a $500 \mathrm{~mL}$ two neck round bottom flask was added solid sodium bicarbonate $(9.3 \mathrm{~g}, 110.7 \mathrm{mmol})$ followed by a solution of Fmoc-OSu (20.5 g, $60.76 \mathrm{mmol})$ in THF (140 $\mathrm{ml}$ ). The latter was added dropwise using a dropping funnel over 30 minutes. The reaction mixture was stirred overnight at room temperature, after which the THF was separated and the aqueous phase was washed with diethyl ether $(3 \times 25$ $\mathrm{mL})$. The combined organic extracts were washed with $\mathrm{H}_{2} \mathrm{O}$, separated, dried over anhydrous magnesium sulphate, filtered and concentrated under reduced pressure to afford yellow viscous oil $(18 \mathrm{~g})(4)$ that was directly used in the next step without purification.

\section{2-(9H-Fluoren-9-methoxycarbonylamino)-1-methyl-} hydrazine (5)

TFA $(50 \mathrm{~mL})$ was added to the yellow oil (4) obtained above- and the reaction mixture was stirred, at room temperature, overnight. The reaction mixture was then concentrated under vacuum in a well-ventilated fume hood to give reddish viscous oil. The residual oil was dissolved in $\mathrm{H}_{2} \mathrm{O}$ /ethyl acetate mixture $(50 / 30 \mathrm{~mL})$, stirred at room tem$\mathrm{H}_{2} \mathrm{O} /$ ethyl acetate mixture $(50 / 30 \mathrm{~mL})$, stirred at room tem-
perature and sodium bicarbonate solid was added till no effervescence was observed ( $\mathrm{pH} 9)$. A white precipitate was formed, which was filtered, washed with ethyl acetate ${ }^{-}$and dried under vacuum to afford $12.56 \mathrm{~g}(84.6 \%)$ of $2-(9 \mathrm{H}-$ Fluoren-9-methoxycarbonylamino)-1-methylhydrazine (5) as a white powder of melting point $145-150^{\circ} \mathrm{C} .{ }^{1} \mathrm{H}$ NMR
$\left(\mathrm{CDCl}_{3}, 400 \mathrm{MHz}\right) 67.94-7.32(\mathrm{~m}, 8 \mathrm{H}), 6.24(\mathrm{br} \mathrm{s}, 1 \mathrm{H}), 4.40$ $\left(\mathrm{CDCl}_{3}, 400 \mathrm{MHz}\right) 6$ 7.94-7.32 (m, 8H), $6.24(\mathrm{br} \mathrm{s}, 1 \mathrm{H}), 4.40$ $(\mathrm{d}, 2 \mathrm{H}), 4.16(\mathrm{t}, 1 \mathrm{H}), 2.58(\mathrm{~s}, 3 \mathrm{H}) ;{ }^{13} \mathrm{C}$ NMR $\left(\mathrm{CDCl}_{3}, 100\right.$
$\mathrm{MHz}) 6 \quad 157.13,143.73,141.36,127.76,127.07,124.97$, 120.01, 67.01, 47.24, 39.29; ESI-Mass $m / z$ 291.3 [M +Na $]^{+}$.

Coupling of 1-chlorocarbonyl-2-(9H-Fluoren-9methoxycarbonylamino)-1-methylhydrazine (6) to ValPro-Phe-Tyr-Resin (7) (Scheme 1, Route A)

To a $50 \mathrm{~mL}$ round bottom flask, containing a cold solution $\left(-10^{\circ} \mathrm{C}\right)$ of triphosgene $(0.66 \mathrm{mmol}, 196 \mathrm{mg})$ and $2-(9 \mathrm{H}-$ Fluoren-9-methoxycarbonylamino)-1-methylhydrazine (5) (2 mmol, $536 \mathrm{mg}$ ) in $15 \mathrm{~mL}$ THF, was added drop wise $\mathrm{N}$ methylmorpholine ( $2 \mathrm{mmol}, 220 \mu \mathrm{l}$ in $300 \mu \mathrm{L}$ THF), under stirring. The reaction mixture was then stirred, for 1 hour, at $-10^{\circ} \mathrm{C}$. A white precipitate of $\mathrm{N}$-methylmorpholinium chloride was formed. The reaction mixture was centrifuged at $2000 \mathrm{x} \mathrm{g}$ for 5 minutes and the supernatant was separated and concentrated under vacuum. 1-chlorocarbonyl-2- $(9 \mathrm{H}-$ Fluoren-9-methoxycarbonylamino)-1-methylhydrazine (6) residue $500 \mathrm{mg}(1.5 \mathrm{mmol}, 75 \%$ yield $)$ was obtained, ESIMass for sample dissolved in methanol $\mathrm{m} / \mathrm{z} 324.5$ [Fmoc$\left.\mathrm{NH}-\mathrm{N}\left(\mathrm{CH}_{3}\right)-\mathrm{COOCH}_{3}\right]^{+}$. The residue was then used for the microwave-assisted coupling to $\mathrm{H}_{2} \mathrm{~N}$-Val-Pro-Phe-Tyr-Resin (7) with DIEA as activator base, where 1-chlorocarbonyl-2Fmoc-1-methylhydrazine /DIEA (1/2). The reaction was repeated for 7 cycles (coupling completion was monitored by Kaiser Test); each coupling utes, at 22 Watts, at a temperature of $75^{\circ} \mathrm{C}$. After coupling completion, the peptide was cleaved from the resin and puri-
Commented [ME1]: Please insert the following legend for figure 1:

Figure 1. Smac/DIABLO-derived N-terminal sequence AVPI (dark grey with Ala in black) in the XIAP BIR3 binding pocket (light grey) the ligand are visualized; generated from PDB: 1G3F [19] 
fied using RP-HPLC (check under general protocols for the MW-SPPS) to obtain AzaAla-Val-Pro-Phe-Tyr- $\mathrm{NH}_{2}$ (2) $(8 \%$ yield and $98 \%$ purity after semi-preparative RP-HPLC purification), ESI-Mass m/z: $618.6[\mathrm{M}+\mathrm{Na}]^{+}$

Coupling of 2-(9H-Fluoren-9-methoxycarbonylamino)-1methylhydrazine (5) to Val-Pro-Phe-Tyr-Resin (7) (Scheme 1, Routes B and C)

For $0.25 \mathrm{mM}$ scale microwave-assisted synthesis of AzaAla-Val-Pro-Phe-Tyr- $\mathrm{NH}_{2} \quad$ (2), 2-(9H-Fluoren-9methoxycarbonylamino)-1-methylhydrazine (5) $(1.5 \mathrm{mmol}$, $402 \mathrm{mg}, 6$ equivalent $)$ and carbonyldiimidazole $(1.5 \mathrm{mmol}$, $243 \mathrm{mg}, 6$ equivalent) or $p$-nitrophenyl chloroformate (1.5 mmol, $302 \mathrm{mg}, 6$ equivalent) were dissolved in DMF (6 $\mathrm{mL}$ ). DIEA was used as activator base, where 2-Fmoc-1 methylhydrazine (5) /DIEA/carbonyldiimidazole or $p$ nitrophenyl chloroformate $(1 / 2 / 1)$ for one coupling cycle. The coupling reagents were transferred to the microwave reaction vessel for coupling (5) to the resin bound peptide $\mathrm{H}_{2} \mathrm{~N}$-Val-Pro-Phe-Tyr-Resin (7). The reaction was repeated for 7 cycles (coupling completion was monitored by Kaiser Test and ESI-MS); each coupling cycle was performed for 10 minutes, at 22 Watts, at a temperature of $75^{\circ} \mathrm{C}$.

\section{Aminopeptidase Susceptibility Assays}

In $1.5 \mathrm{~mL}$ microcentrifuge tube, $940 \mu \mathrm{L}$ of assay buffer (DPP-IV assay buffer: $25 \mathrm{mM}$ Tris, $140 \mathrm{mM} \mathrm{NaCl}$ and 10 $\mathrm{mM} \mathrm{KCl}$ at $\mathrm{pH} 7.9$; LAP assay buffer: $200 \mathrm{mM}$ Tris and 200 $\mathrm{mM} \mathrm{NaCl}$ at $\mathrm{pH} 8.5$ ) and $10 \mu \mathrm{L}$ of peptide DMSO solution $\left(5 \mathrm{mM}\right.$ final concentration) were incubated at $37^{\circ} \mathrm{C}$ with/without $50 \mu \mathrm{L}$ of aminopeptidase enzyme (final conwith/without $50 \mu \mathrm{L}$ of aminopeptidase enzyme (final concentrations of $150 \mathrm{ng} / \mathrm{mL}$ for DPP-IV "human recombinant
enzyme expressed in SF9 cells" and $3.6 \mathrm{mg} / \mathrm{mL}$ for microenzyme expressed in SF9 cells" and $3.6 \mathrm{mg} / \mathrm{mL}$ for micro-
somal LAP enzyme type IV-S "from porcine kidney microsomes"). The reaction mixture was sampled $(100 \mu \mathrm{L})$ at certain time points $(\mathrm{t}=$ zero, $30,60,90,120,180,240,300$ and 360 minutes) and the reaction was quenched for each sample 360 minutes) and the reaction was quenched for each sample
by incubation in a water bath at $95^{\circ} \mathrm{C}$ followed by immediate cooling on ice for $15 \mathrm{~min}$. The samples were injected onto an analytical RP-HPLC to check the peptide degradation/stability (using the same analytical RP-HPLC protocol described under general protocols for the MW-SPPS).

\section{Caspase-9 Activity Fluorimetric Assay}

MDA-MB-231 cell lysate was prepared by solubilising cells pellet $\left(\sim 5 \times 10^{7}\right.$ cells $)$ in $1 \mathrm{~mL}$ ice cold lysis buffer $(50$ $\mathrm{mM} \mathrm{KCl}, 5 \mathrm{mM}$ EGTA, $2 \mathrm{mM} \mathrm{MgCl}_{2}, 1 \mathrm{mM}$ DTT, $0.2 \%$ (w/v) CHAPS and $50 \mathrm{mM}$ HEPES; pH 7.4), supplemented with a protease inhibitor cocktail $(50 \mu \mathrm{g} / \mathrm{mL}$ Antipain. $2 \mathrm{HCl}$, $40 \mu \mathrm{g} / \mathrm{mL}$ Bestatin, $6 \mu \mathrm{g} / \mathrm{mL}$ Chymostatin, $7 \mu \mathrm{g} / \mathrm{mL}$ Pepstatin, $50 \mu \mathrm{g} / \mathrm{mL}$ Phosphoramidon, $1 \mathrm{mg} / \mathrm{mL}$ Pefabloc SC, $0.5 \mathrm{mg} / \mathrm{mL}$ EDTA-Na 2 and $2 \mu \mathrm{g} / \mathrm{mL}$ Aprotinin), and was incubated on ice for $15 \mathrm{~min}$. Cytochrome c $(5 \mu \mathrm{L} ; 1 \mathrm{mg} / \mathrm{mL})$ and dATP $(5 \mathrm{mM})$ in assay buffer $(10 \mathrm{mM}$ HEPES, $0.5 \mathrm{mM}$ EGTA, $5 \mathrm{mM}$ DTT and $10 \%(\mathrm{v} / \mathrm{v})$ glycerol; $\mathrm{pH}$ 7.4) were added to $25 \mu \mathrm{L}$ cell lysate into a $1.5 \mathrm{~mL}$ microcentrifuge with/without $1 \mu \mathrm{L}$ rhXIAP BIR3 $(500 \mathrm{nM}$ final concentra-
tion) and with/without $0.5 \mu \mathrm{L}$ treatment peptide in DMSO (final concentrations of $1 \mu \mathrm{M}$ ), which were then incubated at $37^{\circ} \mathrm{C}$ for $1 \mathrm{~h}$. Each reaction mixture was then diluted with 65 $\mu \mathrm{L}$ assay buffer; all were transferred to 96-well microtiter plate and then $5 \mu \mathrm{L}$ of Ac-LEHD-AFC substrate $(50 \mu \mathrm{M}$ final concentration) were added per well. A FLUOstar OPTIMA spectrofluorimeter (BMG LABTECH, Ortenberg, Germany) was used at excitation wavelength of $380-40$ the determine the caspase-9 activity through the Ac-LEHD-AFC substrate cleavage with the release of 7-amino-4 trifluoromethylcoumarin fluores-cent moiety. The reactions were monitored for $1 \mathrm{~h}$. Reactions were carried out in triplicates for accuracy. Finally, percent caspase-9 release was calculated from the following formula:

$\%$ caspase 9 derepression $=100 \mathrm{X}$ [slope of treatment curve fit/slope of maximum activation (dATP + cyt.c) curve fit]

\section{RESULTS AND DISCUSSION}

\section{Synthesis of AzaAla-Val-Pro-Phe-Tyr-NH 2 (2)}

The Micro-Wwave-assisted solid phase synthesis (MWSPPS) of the target peptide included the coupling of $2-(9 \mathrm{H}-$ Fluoren-9-methoxycarbonylamino)-1-methylhydrazine (5) to the tetrapeptide sequence Val-Pro-Phe-Tyr-tethered to the resin (7) (Scheme 1), but first the synthesis of (5) was required. Compound (5) was synthesized from 1-(tertbutoxycarbonyl)-1-methylhydrazine (3), using the previously reported synthesis protocol by Busnel et al. [22] and others [23-25]. The synthesis comprises two steps, an initial Fmocprotection of the primary amino function of the hydrazine, followed by Boc removal of the secondary amine functionality (Scheme 1). The introduction of the Fmoc-group was accomplished using Fmoc-OSu, in the presence of sodium bicarbonate, to obtain (4), which was then treated with TFA in order to effect the removal of the Boc-group. The final product, N-Fmoc-methyhydrazine (5), was obtained in high yield ( $85 \%$, based on the starting amount of 4$)$.

The synthesis of the target Aza-peptide (2) was achieved as shown in Route A (Scheme 1) through the activation of (5) by treatment with triphosgene in the presence of $\mathrm{N}$ methyl morpholine, at $-10^{\circ} \mathrm{C}$ in THF. The product, 1 -chloromethyl morpholine, at $-10^{\circ} \mathrm{C}$, in THF. The product, $1-c h$ carbonyl-2-(9H-Fluoren-9-methoxycarbonylamino)-1-
methylhydrazine (6) was obtained in high yield $(75 \%$,based on the amount of starting material 5) and was used directly to acylate the resin-bound $\mathrm{H}_{2} \mathrm{~N}$-Val-Pro-Phe-Tyr-sequence (7) using microwave-assisted coupling, employing DIEA as subjected to the Kaiser Test and ESI-MS, in order to assess the extent of coupling (6). It was found that seven repeat coupling cycles $\left(10\right.$ minutes/cycle, 22 Watts, $\left.75^{\circ} \mathrm{C}\right)$ were required for completion of the reaction.

Boeglin and Lubell have previously shown that coupling of various Fmoc-aza-amino acid chlorides (including 6) to the $\mathrm{N}$-terminus amino group of resin tethered peptides is only complete after $6 \mathrm{~h}$ reaction in DCM with DIEA as acti. Employing microwave-assisted coupling, we managed to significantly reduce the coupling reaction time to 70 minutes ( 7 cycles x 10 minutes/cycle). Unfortunately, even with this repetitive coupling protocol, (2) could only be obtained as a low purity $(25 \%)$ crude product, as estimated by analytical
Formatted: Justified 


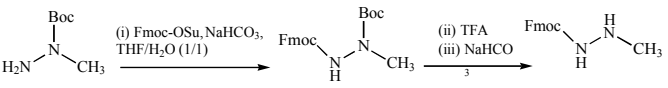

(3)

(4)

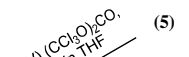



(6)
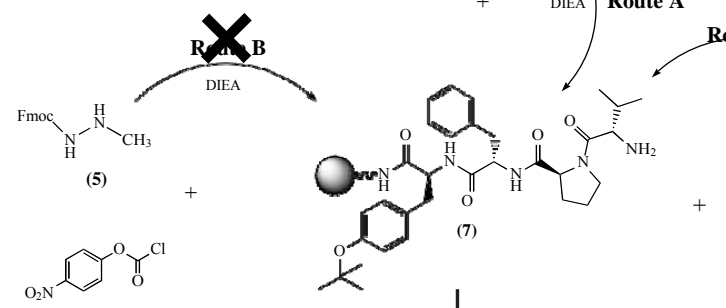

P-Nitrophenyl chloroformat


Scheme 1. On resin microwave-assisted coupling of 2-(9H-Fluoren-9-methoxycarbonylamino)-1-methylhydrazine (5) for the synthesis of AzaAla-Val-Pro-Phe-Tyr- $\mathrm{NH}_{2}$ (2); triphosgene activation (Route A), $p$-nitrophenyl chloroformate activation (Route $\mathrm{B}$ ) and carbonyldiimidazole activation (Route C).

RP-HPLC (data not shown). This could be due to the infeasibility of purifying the highly active and unstable intermediate (6), which necessitates using it as a crude product for coupling to the resin bound peptide (7). However, the crude Aza-peptide (2) was purified successfully, by semipreparative RP-HPLC, to give a final product with a yield of preparative RP-HPC,

Triphosgene is not compatible for use within a microwave-assisted synthesizer, due to it being highly reactive and with potential for interaction with the amide groups of the microwave compatible solvents DMF and NMP. Therefore in attempts to improve the yield and purity of the product and to automate the synthesis, additional carbonylating agents were tried for coupling $N$-Fmoc-methylhydrazine (5) 


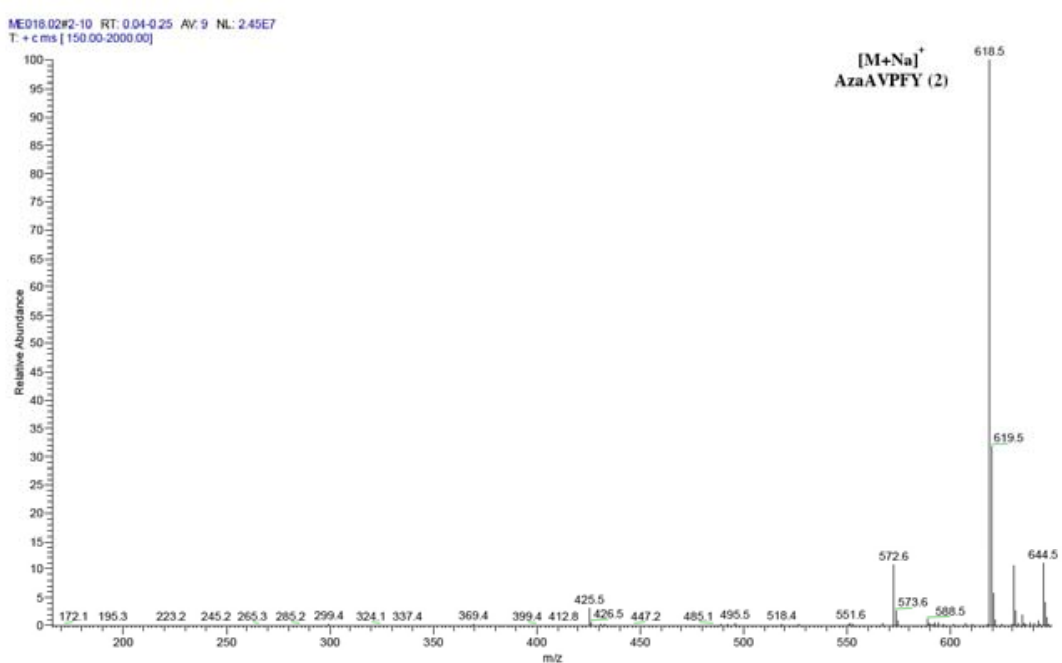

(A)

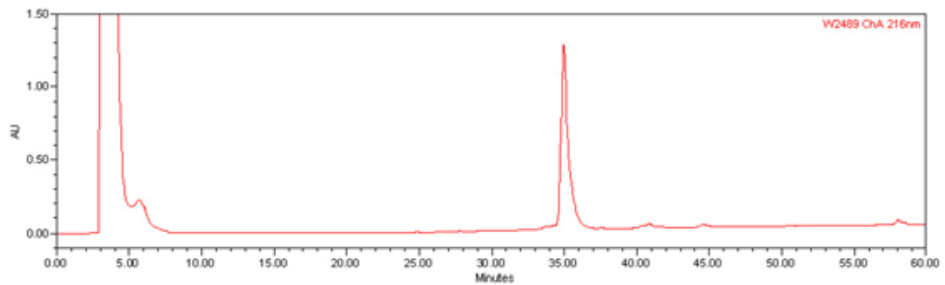

(B)

Figure 3. Panel (A) is ESI-MS data for purified AzaAla-Val-Pro-Phe-Tyr- $\mathrm{NH}_{2}$ (2) (calcd. m/z: 595, found m/z: 618 [M+Na] $]^{+}, 100 \%$ relative abundance) produced by triphosgene-mediated carbonylation of $N$-Fmoc-methylhydrazine (5). Panel (B) is the analytical RP-HPLC spectrum for purified aza-peptide (2) of retention time $35 \mathrm{~min}$ (peak identified by ESI-MS).

to the N-terminal amino group of the resin-tethered peptide (7), under microwave conditions. We tried both paranitrophenyl chloroformate (Scheme 1, Route B) and carbonyldiimidazole (Scheme 1, Route C) mediated carbonylation and coupling using the conditions described in the experimental section. Disappointingly, we did not obtain any of the target peptide, even after 7-repeat coupling cycles in case of para-nitrophenyl chloroformate (data not shown) and incomplete coupling was observed when carbonyldiimidazole was used as activator, as indicated by ESI-MS analysis (Fig. 4) Similar observations have been reported by Han et al. the attempted incorporation of two aza-amino acids into target sequences when using para-nitrophenyl chloroformate and carbonyldiimidazole [26]. This could be due to a low inherent reactivity of the respective aryl carbamates and $\mathrm{N}$ - carbonyl imidazoles, or the poor accessibility of these derivatives to the amino functionality of the tethered peptide within the resin matrix, as reported by André et al. [27]. Ultimately, the AzaAla-Val-Pro-Phe-Tyr- $\mathrm{NH}_{2}$ (2) synthesis was only successful through the triphosgene-mediated carbonylation approach (Scheme 1, route A).

\section{Aminopeptidase Susceptibility}

Compound (2) was then tested for its stability against two aminopeptidases; namely LAP and DPP-IV, and in comparison to the wild-type Smac-derived native sequence Ala-ValPro-Phe-Tyr- $\mathrm{NH}_{2}(\mathbf{1})$ and the $\mathrm{N}$-methyl alanyl analogue $\mathrm{N}$ Me-Ala-Val-Pro-Phe-Tyr- $\mathrm{NH}_{2}$ (9). 


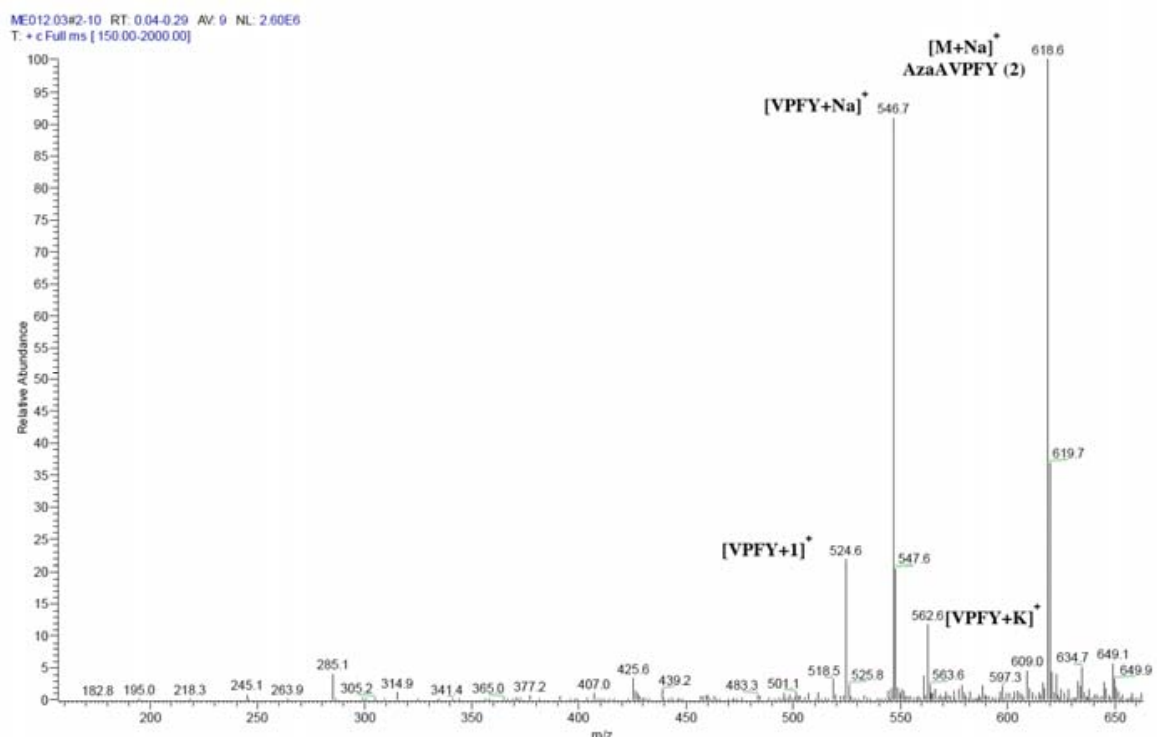

Figure 4. ESI-MS trace for crude AzaAla-Val-Pro-Phe-Tyr- $\mathrm{NH}_{2}$ (2) produced by carbonyldiimidazole-mediated carbonylation of $N$-Fmocmethylhydrazine (5) showing peaks of unreacted Val-Pro-Phe-Tyr- $\mathrm{NH}_{2}$ even after 7-repeated coupling cycles, indicating incomplete coupling.

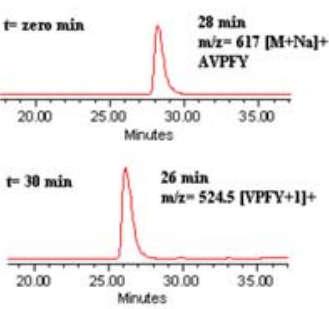

(a)

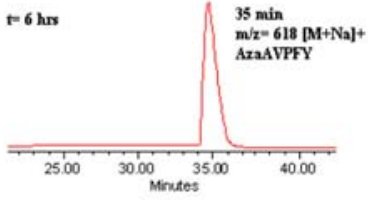

(b)

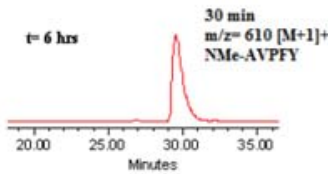

(c)

Figure 5. RP-HPLC profiles of (a), Smac-derived pentapeptide analogue (1) incubated with LAP, for $30 \mathrm{~min}$, at $37^{\circ} \mathrm{C}(\mathbf{b})$, AzaAla-analogue (2) and (c), N-Me-analogue (9) incubated with LAP, for $6 \mathrm{~h}$, at $37^{\circ} \mathrm{C}$

LAP is an aminopeptidase that can cleave N-terminal Ala residues from peptides [28]. As anticipated, the P1 Ala residue was completely hydrolysed from the native peptide sequence (1) in 30 minutes, to give the truncated hydrolysis product Val-Pro-Phe-Tyr-NH $\mathrm{N}_{2}$, as shown by RP-HPLC and product Val-Pro-Phe-Tyr-NH
ESI-MS (Fig. 5 (a)). Strikingly, the AzaAla-analogue (2) was completely resistant to hydrolysis after $6 \mathrm{~h}$ of exposure to LAP (Fig. 5 (b)), as was the case with the N-methyl alanyl protected analogue (9) (Fig. 5 (c)). These results suggest that designing Smac-derived analogues with a planar $\mathrm{SP}^{2}$ hybridised Aza-alanyl modified N-terminal will improve the proteolytic resistance for those candidates, making them as resistant as the widely used $\mathrm{N}$-methyl alanyl congeners.

Interestingly, the Smac-derived pentapeptide analogue (1), AzaAla-analogue (2) and N-Me-Ala-analogue (9) proved to be resistant to aminopeptidase DPP-IV after $6 \mathrm{~h}$ exposure to the enzyme, as observed by RP-HPLC and ESI-MS (data not shown). Although DPP-IV is an N-terminal dipeptidyl 


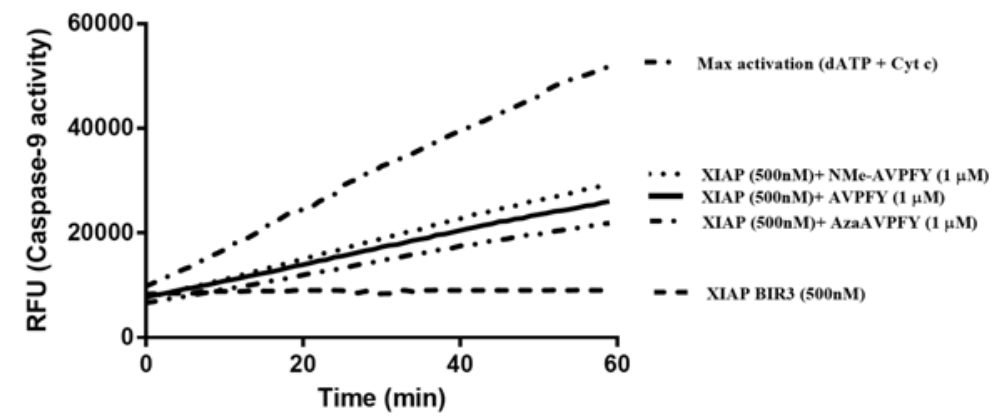

Figure 6. Caspase-9 activation data for the N-terminal Smac-derived peptide library.

peptidase that can cleave a dipeptide unit in 'one bite' from longer peptides with Val at the P2 position [29], it might have been expected that all the three Smac-derived peptides (1), (2) and (9) would have been subject to degradation by this peptidase (they all have Val at P2). However, the presence of Pro at P3 makes all of the N-terminal Smac-derived sequences intrinsically resistant to DPP-IV, since peptides with Pro at P3 are known to function as DPP-IV inhibitors [30].

\section{IAP Antagonistic Activity}

Subsequently, the antagonistic activity of AzaAlaanalogue (2) against XIAP BIR3 was assessed by caspase-9 analogue (2) against XIAP BIR3 was assessed by caspase- 9 derived analogues to reactivate caspase- 9 in the presence of its inhibitor rhXIAP BIR3 (500 nM) was determined by the increase in caspase- 9 activity that they induced.

Remarkably, the Aza-peptide analogue (2) retained the ability to antagonise the inhibitory effect of XIAP BIR3 on caspase-9 activation as effective as the wild-type (1) and the N-Methyl-Ala- sequence (9) (Fig. 6). In essence, (2) was able to restore $36.2+4.9 \%$ of caspase- 9 activity in the presence of $500 \mathrm{nM}$ rhXIAP BIR3, at $1 \mu \mathrm{M}$ compared to $43.1+$ $5.2 \%$ for the wild sequence (1) and $51.4+7.1 \%$ for the NMe-Ala-analogue (9), at the same concentration (mean $\pm \mathrm{SD}$, $n=3$ ) (Fig. 6). These results demonstrate that the planar conformation of the $\mathrm{SP}^{2}$ hybridised AzaAla residue did not dramatically miss-locate the side-chain methyl group at P1 permitting the essential hydrophobic interaction with the indole
ring of the W310 residue of XIAP BIR3 (Fig. 1 [3]). Moreoring of the W310 residue of XIAP BIR3 (Fig. 1 [3]). Moreo-
ver, analogue (2) can still form the essential electrostatic interaction with the proximal Glu314 of XIAP BIR3, owing to the retained and unmodified N-terminal primary amino function of the AzaAla residue (Fig. 1 [3]).

\section{CONCLUSION}

In the light of the above results, the modified peptide AzaAla-Val-Pro-Phe-Tyr- $\mathrm{NH}_{2}$ (2) was a successful bioisostere for the N-terminal Smac-derived pentapeptide parent sequence Ala-Val-Pro-Phe-Tyr- $\mathrm{NH}_{2}$ (1). The Aza-peptide (2) is an equipotent analogue for (1) as a XIAP BIR3 inhibi- tor, whilst exhibiting enhanced stability towards aminopeptidases, exemplified mainly by LAP, owing to the planar geometry of the Aza-Ala residue at P1. Although the reported Aza-peptide (2) is not a therapeutic candidate per se, due to lack of cell permeability, it represents an important lead lack of cell permeability, it represents an important lead compound for the development of a new class of anti-cancer
Smac-derived Aza-peptidomimetic therapeutic candidates. Our current studies focus on developing libraries of these novel candidates, where the N-terminal Ala residue at P1 is occupied with the Aza-Ala isostere instead of the widely modified as previously reported by ourselves $[3]^{3}$ and others $[4]^{4}$. These structural modifications of the arising Smacderived

Aza-peptidomimetics are expected to improve the efficacy and proteolytic stability of these therapeutic candidates.

\section{LIST OF ABBREVIATIONS}

IAPs

$=$ Inhibitor of Apoptosis Proteins

Smac $=\underline{\text { Second }}$ mitochondria-derived activator of caspases


Baculovirus IAP Repeat- $\underline{3}$ domain

SAR $=$ Structure Activity Relationship

LAP $=$ Leucine Aminopeptidase

DPP-IV = Dipeptidyl Peptidase-IV

\section{CONFLICT OF INTEREST}

The authors declare there is no conflict of interest for this research work

\section{ACKNOWLEDGEMENT}

This work has been funded by the Dr John King foundation grant, School of Pharmacy, Queen's University of Belfast.

\section{REFERENCES}

[1] Fulda, S.; Wick, W.; Weller, M.; Debatin, K.-M. Smac agonists sensitize for Apo2L/TRAIL- or anticancer drug-induced apoptosis 
and induce regression of malignant glioma in vivo. Nat. Medicine, [2] Arnt, C. R.; Chiorea Synthetic Smac/DIABLO Peptides Enhance the Effects of Chemotherapeutic Agents by Binding
Chem., 2002, 277, 44236-44243.

[3] Elsawy, M. A.; Martin, L.; Tikhonova, I. G.; Walker, B. Solid phase synthesis of Smac/DIABLO-derived peptides using a 'SafetyCatch' resin: Identification of potent XIAP BIR3 antagonists. Bioorg. Med. Chem., 2013, 21, 5004-5011.

[4] Oost, T. K.; Sun, C.; Armstrong, R. C.; Al-Assaad, A.; Betz, S. F.; Deckweth, T. L.; Ding, H.; Elmore, S. W.; Meadows, R. P.; Olejniczak, E. T.; Olesksijew, A.; Oltersdorf, T.; Rosenberg, S. H.; Shoemaker, A. R.; Tomaselli, K. J.; Zou, H.; Fesik, S. W. Discovery of Potent Antagonists of the Antiapoptotic Protein XIAP for the Treatment of Cancer. J. Med. Chem., 2004, 47,4417-4426.

[5] Sun, H.; Nikolovska-Coleska, Z.; Yang, C. Y.; Xu, L.; Tomita, Y.; Krajewski, K.; Roller, P. P.; Wang, S. Structure-Based Design, Synthesis, and Evaluation of Conformationally Constrained Mimetics of the Second Mitochondria-Derived Activator of Caspase That Target the X-Linked Inhibitor of Apoptosis Protein
teraction Site. J. Med. Chem., 2004, 47,4147-4150.

[6] Sun, H.; Nikolovska-Coleska, Z.; Chen, J.; Yang, C.-Y.; Tomita, Y. Pan, H.' Yoshioka, Y.; Krajewski, K.; Roller, P. P.' Wang S. Structure-based design, synthesis and biochemical testing of novel and potent Smac peptidomimetics. Bioorg. Med. Chem. Lett., 2005, 15, 793-797.

[7] Wist, A. D.; Gu, L.; Riedl, S. J.; Shi, Y.; McLendo, G. L. Structurectivity based study of the Smac-binding pocket within the BIR3 domain of XIAP. Bioorg. Med. Chem., 2007, 15, 2935-2943.

[8] Flygare, J. A.; Fairbrother, W. J. Small-molecule pan-IAP antagonists: a patent review. Expert. Opin. Ther. Pat., 2010, 20,251-267.

Cai, Q.; Sun, H.; Peng, Y.; Lu, J.; Nikolovska-Coleska, Z.; McEachern, D.; Liu, L.;Qiu, S.; Yang, C.-Y.; Miller, R.; Yi, H.; Zhang, T.; Sun, D.; Kang, S.; Guo, M.;Leopol, L.; Yang, D.; Wang, S. A Potent and Orally Active Antagonist (SM-406/AT-406) of Multiple Inhibitor of Apoptosis Proteins (IAPs) in Clinical Devel-

[10] Simone, F. Molecular pathways: targeting inhibitor of apoptosis proteins in cancer--from molecular mechanism to therapeutic appliproteins in cancer--from molecular mechanis
cation. Clin. Cancer Res., 2014, 20, 289-295.

[11] Houghton, P. J.; Kang, M. H.; Reynolds, C. P.; Morton, C. L. Kolb, E. A.; Gorlick, R.; Keir, S. T.; Carol, H.; Lock, R.; Maris, J. M.; Billups, C. A.; Smith, M. A. Initial testing (stage 1) of LCL161, a SMAC mimetic, by the pediatric preclinical testing program. $\mathrm{Pe}$ diatr. Blood Cancer, 2011, 58, 636-639.

[12] Chen, K.-F.; Lin, J.-P.; Shiau, C.-W.; Tai, W.-T.; Liu, C.-Y.; Yu, H.-C.; Chen, P.-J.; Cheng, A.-L. Inhibition of Bcl-2 improves effect of LCL161, a SMAC mimetic, in hepatocellular carcinoma cells.

[13] Cai, Q.; Sun, H.; Peng, Y.; Lu, J.; Nikolovska-Coleska, Z.; McEachern, D.; Liu, L.; Qiu, S.; Yang, C.-Y.; Miller, R.; Yi, H.; Zhang, T.; Sun, D.; Kang, S.; Guo, M.; Leopold, L.; Yang, D.; Wang, S. A Potent and Orally Active Antagonist (SM-406/AT-406) velopn 2726 .

[14] Zhang, T.; Li, Y.; Zou, P.; Yu, J.-y.; McEachern, D.; Wang, S.; Sun, D. Physiologically based pharmacokinetic and pharmacody-
namic modeling of an antagonist (SM-406/AT-406) of multiple innamic modeling of an antagonist (SM-406/AT-406) of multiple in-
hibitor of apoptosis proteins (IAPs) in a mouse xenograft model of
human breast cancerPBPK/PD Modelong of an Antagonist of IAPs. Biopharm. Drug Dispos., 2013, 34, 348-359.

[15] Flygare, J. A.; Beresini, M.; Budha, N.; Chan, H.; Chan, I. T. Cheeti, S.; Cohen, F.; Deshayes, K.; Doerner, K.; Eckhardt, S. G.; Elliott, L. O.; Feng, B.; Franklin, M. C.; Reisner, S. F.; Gazzard, L.; Halladay, J.; Hymowitz, S. G.; La, H.; LoRusso, P.; Maurer, B. Murray, L.; Plise, E.; Quan, C.; Stephan, J.-P.; Young, S. G.; Tom, J.; Tsui, V.; Um, J.; Varfolomeev, E.; Vucic, D.; Wagner, A. J.; Wallweber, H. J. A.; Wang, L.; Ware, J.; Wen, Z.; Wong, H.; Wong, J. M.; Wong, M.; Wong, S.; Yu, R.; Zobel, K.; of inhibitor of apoptosis (IAP) proteins and clinical candidate for the treatment of cancer (GDC-0152). J. Med. Chem., 2012, 55, $4101-4113$

[16] Wong, H.; Gould, S. E.; Budha, N.; Darbonne, W. C.; Kadel, E. E.; La, H.; Alicke, B.; Halladay, J. S.; Erickson, R.; Portera, C.; Tolcher, A. W.; Infante, J. R.; Mamounas, M.; Flygare, J. A.; Hop, C C. E. C. A.; Fairbrother, W. J. Learning and Confirming with Preclini0917, an Inhibitor of Apoptosis Proteins Antagonist. Drug Metab. Dispos., 2013, 41, 2104-2113.

[17] Condon, S. M.; Mitsuuchi, Y.; Deng, Y.; LaPorte, M. G.; Rippin, S. R.; Haimowitz, T.; Alexander, M. D.; Kumar, P. T.; Hendi, M. S.; Lee, Y.-H., Benetatos, C. A., Yu, G., Kapoor, G. S., Nein Seipel, M. E.; Burns, J. M.; Graham, M. A.; McKinlay, M. A.; Li, X.; Wang, J.; Shi, Y.; Feltham, R.; Bettjeman, B.; Cumming, M. H.; Vince, J. E.; Khan, N.; Silke, J.; Day, C. L.; Chunduru, K S. Birinapant, a Smac-Mimetic with Improved Tolerability for the Treatment of Solid Tumors and Hematological Malignancies. J.

[18] Benetatos, C. A.; Mitsuuchi, Y.; Burns, J. M.; Neiman, E. M.; Conon, S. M.; Yu, G.; Seipel, M. E.; Kapoor, G. S.; La Porte, M. G.;

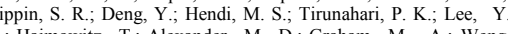
H.; Haimowitz, T.; Alexander, M. D.; Graham, M. A.; Weng, D.; Shi, Y.; McKinlay, M. A.; Chunduru, S. K. Birinapant cIAPs, Abrogates TNF-Induced NF-nB Activation, and Is Active in Patient-Derived Xenograft Models. Mol. Cancer Ther., 2014 13, 867-879.

[19] Liu, Z.; Sun, C.; Olejniczak, E. T.; Meadows, R. P.; Betz, S. F.; Oost, T.; Herrmann, J.; Wu, J. C.; Fesik, S. W. Structural basis for binding of Smac/DIABLO to the XIAP BIR3 domain. Nature,

[20] Wu, G.; Chai, J. Suber, T. L.; Wu, J-W · Du, C.; Wang, X.; Shi, Y . Structural basis of IAP recognition by Smac/DIABLO. Nature, 2000, 408, 1008-1012

[21] Proulx, C.: Sabatino, D.; Hopewell, R.; Spiegel, J.; Ramos, G. Y.; Lubell, W. D. Azapeptides and their therapeutic potential. Future Med Chem., 2011, 3, 1139-1164.

[22] Busnel, O.; Bi, L.; Dali, H; Cheguillaume, A; Chevance, S.; Bondon, A.; Muller S. Baudy-Floc'h, M. Solid-Phase Synthesis of "Mixed" Peptidomimetics Using Fmoc-Protected Aza- $b^{3}$ ids and a-Amino Acids. J. Org. Chem , 2005, 70, 10701-10708.

[23] Gibson, C.: Goodman, S. L. : Hahn, D.; Hölzemann, G; Kessler, H. Novel Solid-Phase Synthesis of Azapeptides and Azapeptoides via Fmoc-Strategy and Its Application in the Synthesis of RGDMimetics. J. Org. Chem., 1999, 64, 7388-7394.

[24] Boeglin, D.; Lubell, W. D. Aza-Amino Acid Scanning of Secondary Structure Suited for Solid-Phase Peptide Synthesis with Fmoc Chemistry and Aza-Amino Acids with Heteroatomic Side Chains.

[25] Boeglin, D.; Xiang, Z.; Sorenson, N. B.; Wood, M. S.; HaskellLuevano, C.; Lubell, W. D. Aza-scanning of the Potent Melanocortin Receptor Agonist Ac-His-p-Phe-Arg-Trp-NH ${ }_{2}$. Chem Biol

[26] Han, H.; Janda, K. D. Azatides: Solution and Liquid Phase Syntheses of a New Peptidomimetic. J. Am. Chem. Soc., 1996, 118, 2539-

[27] André, F.; Marraud, M.; Boussard, G. Synthesis and structure of AzAsx-P

[28] Gu, Y.-Q. Walling, L. L. Specificity of the wound-induced leucine minopeptidase (LAP-A) of tomato. Eur. J. Biochem., 2000, 267, aminopeptic.

[29] Martin, R. A.; Cleary, D. L.; Guido, D. M.; Zurcher-Neely, H. A.; Kubiak, T. M. Dipeptidyl peptidase IV (DPP-IV) from pig kidney (bGRF) modified at position 2 with Ser, Thr or Val. Extended DPP-IV substrate specificity?. Biochim. Biophys. Acta, 1993, 1164,252-260.

[30] Hoffmann, T.; Reinhold, D.; Kähne, T.; Faust, J.; Neubert, K.; Frank, R.; Ansorge, S. Inhibition of dipeptidyl peptidase IV (DP V) by anti-DP IV antibodies and non-substrate X-X-Prooligopeptides ascertained by capillary electrophoresis. $J$. Chroma- 